\title{
Heterogeneous Nuclear Ribonucleoprotein M
}

National Cancer Institute

\section{Source}

National Cancer Institute. Heterogeneous Nuclear Ribonucleoprotein M. NCI Thesaurus. Code C98157.

Heterogeneous nuclear ribonucleoprotein $\mathrm{M}(730 \mathrm{aa}, \sim 78 \mathrm{kDa})$ is encoded by the human HNRNPM gene. This protein plays a role in the mediation of RNA splicing. 